\title{
Wildlife genetics and disease: allozyme evolution in the wild boar ( Sus scrofa) caused by a swine fever epidemy
}

\author{
Stéphane LANG ${ }^{\mathrm{a}, *}$, Bernard PESSON ${ }^{\mathrm{a}}$, Francois KLeIN ${ }^{\mathrm{b}}$, Arnd \\ SCHREIBER $^{c}$ \\ ${ }^{a}$ Faculté de Pharmacie, Université Louis Pasteur, \\ 74 Route du Rhin, 67400 Illkirch-Graffenstaden, France \\ ${ }^{b}$ Office national de la chasse, \\ Au bord du Rhin, 67150 Gerstheim, France \\ ${ }^{c}$ Zoologisches Institut I, Universität Heidelberg, \\ Im Neuenheimer Feld 230, 69120 Heidelberg, Deutschland
}

(Received 13 September 1999; accepted 23 February 2000)

\begin{abstract}
Enzyme polymorphism at 42 loci was compared before and after a major epidemy of swine fever in wild boars from northern Vosges (France). No change was observed in the 38 monomorphic loci, but allele frequencies at the phosphoglucomutase locus PGM-2* changed significantly. Possible causes for this observation are discussed, and it appears that PGM-2 locus could be a genetic marker of resistance to this viral disease.

population genetics / wild boar / Sus scrofa / hog cholera / natural selection

Résumé - Génétique des populations naturelles et pathologie : évolution du polymorphisme enzymatique chez le sanglier (Sus scrofa) en relation avec une épidémie de peste porcine. L'analyse du patrimoine génétique des sangliers sauvages des Vosges du nord (France) ayant survécu à la peste porcine de 1992 et de leurs descendants a été conduite à travers l'étude du polymorphisme électrophorétique à 42 locus. Aucun changement n'a été observé pour les 38 locus monomorphes au départ, mais les fréquences des allèles de la phosphoglucomutase ont évolué significativement en comparaison avec celles observées avant l'apparition de la maladie sur le même territoire L'origine de cette variation est discutée, et il semble que le locus PGM-2* pourrait être le marqueur d'une résistance génétique à cette maladie virale.
\end{abstract}

génétique des populations / sanglier / Sus scrofa / peste porcine / sélection

\footnotetext{
* Correspondence and reprints

E-mail: stephane.lang1@libertysurf fr
} 


\section{INTRODUCTION}

The wild boar (Sus scrofa) is susceptible to be infected with the classical swine fever (CSF) or hog cholera virus $[1,5,7,10,14]$. The infectious agent, a virus of the Pestivirus group (Flaviviridae), is transmitted whenever pigs scavenge carcasses or eat slaughter offal or kitchen remains containing the CSF virus. Transmission usually occurs from the domestic to the wild pig population, but the latter may serve as a reservoir to reinfect farm hogs. CSF has become a major hygienic and economic problem for pork breeders in several countries. Mortality is usually very high, often eradicating $90 \%$ of a local wild boar population, or more [5]. Juveniles may succumb to the CSF virus 4-7 days after infection, but adults may live for a further 2-3 weeks or even for months. A few adult wild boars can survive the infection [5]. The individual susceptibility depends on the general health status, nutritional status, parasite load and social stress.

In December 1991, conspicuous wild boar mortality was observed in the northern Vosges mountains (NE France), close to the French-German border (Fig. 1), and developed into a CSF epidemy in the departments of Bas-Rhin and Moselle from January 1992 onward. Of 2797 wild boar sera examined from January 1992 to February 1994, 266 contained antibodies against the CSF virus, $10 \%$ of all hunted wild boar and $23 \%$ of the carcasses found in the forest were virus carriers [9]. Wild boars from all age classes became victim of the virus, but the younger animals suffered the most. A total of 215000 hectares, including 126000 hectares of forest, were affected by the epidemy by the end of 1992 . The fenced A4 motorway (Paris-Strasbourg) crossing the Vosges mountains prevented the spread of the disease to the large wild boar populations of the central and southern Vosges. The "green bridge" enabling wildlife to cross this motorway had been blocked. Spatial isolation by the Canal de la Marne au Rhin was reinforced by the erection of a daily controlled electrified fence to separate the infected subpopulation from wild boars living elsewhere in Alsace. Mortality increased rapidly in the early phase of the epidemy from January to April 1992. After November 1993, the epidemy subsided but lingered in several focal areas. Mortality due to CSF decreased until 1997, but occasional cases were observed in the area until spring 1998 at least.

In 1988-1989 wild boars from the northern Vosges were sampled for a genetic survey of their protein polymorphism [4]. On account of the devastating effects of CSF on the Vosgian wild boar, another genetic study appeared interesting to determine the population genetic changes, if any, brought about by a major disease. Epidemies can have substantial consequences on the survival and genetic management of wildlife. In addition, the interaction of diseasecaused mortality and the genetic variability of wild mammals is of interest to conservation biologists and game managers [11].

\section{MATERIALS AND METHODS}

Population. Tissue samples (liver, heart and kidney) of 48 wild boar hunted from shooting stands or during battues were collected in an area of 3500 hectares in the forests of Petersbach, Lohr, Schoenburg, Eschbourg, Dossenheim, 


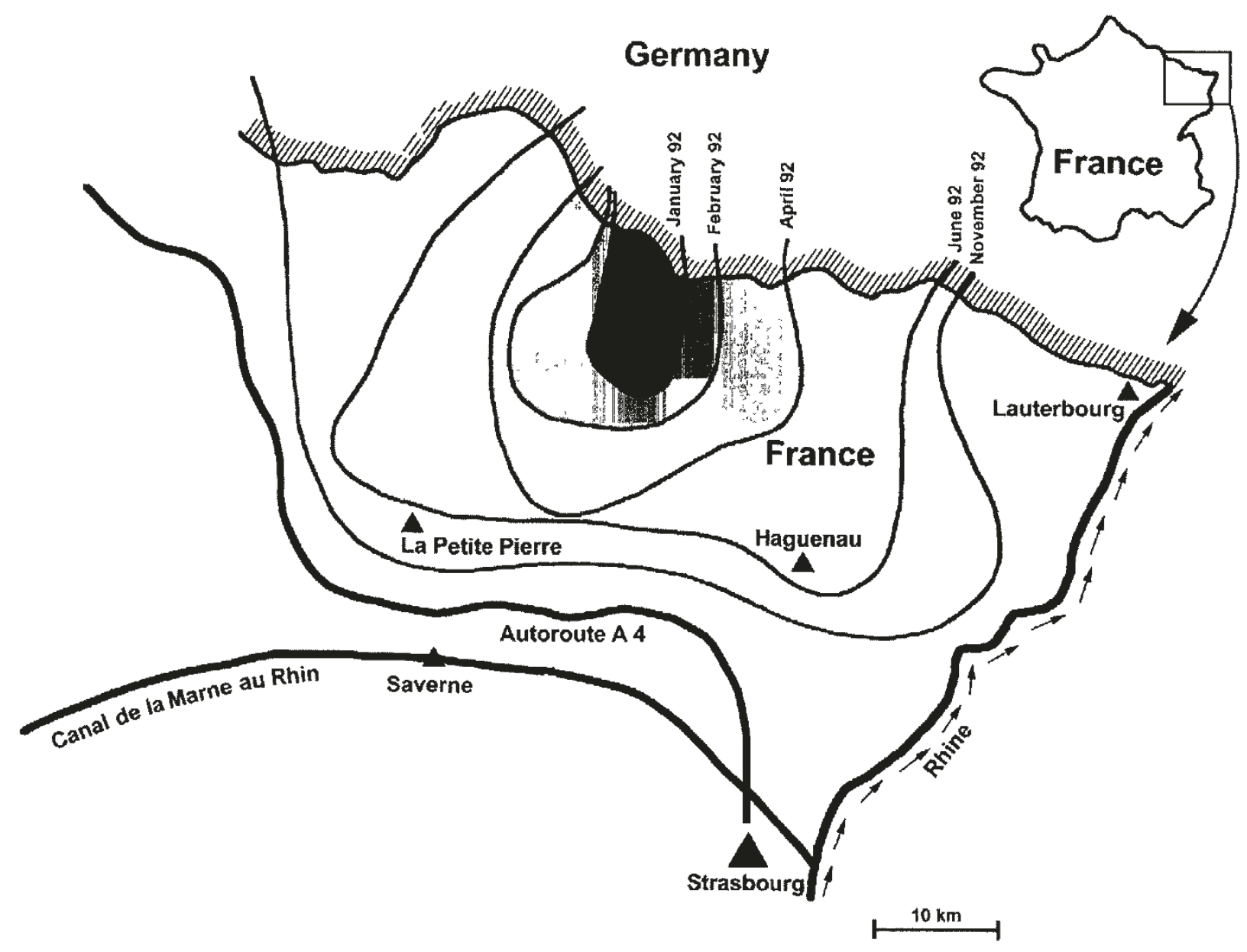

Figure 1. Study area, depicting the core of the classical swine fever epidemy in the wild boar, and its spread over the northern Vosges. 
Neuwiller and La Petite Pierre in Bas-Rhin (Alsace, France) from summer 1994 to 1996, z.e. in the same area sampled by Hartl et al. [4] in 1988-1989 (Fig. 1). The samples were accumulated from 37 hunting events throughout the collection area, thus the predominant coverage of single family groups only can be excluded.

Electrophoresis. The tissue samples were stored frozen until electrophoretic analysis. The identity of the polymorphic alleles encountered in this study with those characterised by Hartl et al. [4] was checked by the exchange of genotyped samples with the Forschungsinstitut für Wildtierkunde und Ökologie (Veterinärmedizinische Universität Wien, Austria). PGM was resolved in a buffer containing $230 \mathrm{mM}$ Tris-citrate $\mathrm{pH}$ 6.2. The following enzymes were studied $(\mathrm{l}=$ liver, $\mathrm{k}=$ kidney, $\mathrm{h}=$ heart): acylase (ACY, EC 3.5.1.14, $\mathrm{k}$ ), aspartate aminotransferase (AAT, EC 2.6.1.1, k), acid phosphatase (ACP, EC 3.1.3.2, $1, \mathrm{k}$ ), adenosine deaminase (ADA, EC 3.5.4.4, l), adenylate kinase (AK, EC 2.7.4.3, k), catalase (CAT, EC 1.11.1.6, k), creatine kinase (CK, EC 2.7.3.2, l, k), diaphorase (DIA, EC 1.8.1.4, l, k), esterase (ES, EC 3.1.1.1, k, substrate: methyl umbelliferyl acetate), fumarase (FUM, EC 4.2.1.2, 1), glucose6-phosphate dehydrogenase (G-6PDH, EC 1.1.1.49, k), glucose dehydrogenase $(\mathrm{GDH}, 1.1 .1 .47, \mathrm{l})$, glutamate dehydrogenase (GLD, EC 1.4.1.2, 1), glucosephosphate isomerase (GPI, EC 5.3.1.9, k), hexokinase (HK, EC 2.7.1.1, k), isocitrate dehydrogenase (IDH, EC 1.1.1.42, $\mathrm{k}$ ), lactate dehydrogenase (LDH, EC 1.1.1.27, k), malate dehydrogenase (MDH, EC 1.1.1.37, 1, k), malic enzyme (ME, EC 1.1.1.40, k), mannose-phosphate isomerase (MPI, EC 5.3.1.8, k), purine nucleotide phorphorylase (NP, EC 2.4.2.1, k), peptidase (PEP, EC 3.4.11, $\mathrm{k}$, substrate: glycyl-leucine and leucyl-alanine), 6-phosphogluconate dehydrogenase (6-PGD, EC 1.1.1.44, k), phosphoglucomutase (PGM, EC 5.4.2.2, l, k), pyruvate kinase (PK, EC 2.7.1.40, h), superoxide dismutase (SOD, EC 1.15.1.1, $\mathrm{k}$ ), xanthine dehydrogenase (XDH, EC 1.1.1.204, l). Sample quality was insufficient to confirm the homology of the zymogrammes with the polymorphic peptidase PEP-1 reported by Hartl et al. [4]. Alleles are designated by their percentage of mobility refering to the most common variant which is defined as " 100 ".

\section{RESULTS}

The majority of the enzymes investigated in the wild boar population sample from the northern Vosges proved monomorphic: ACY-2, AAT-1, AAT-2, ACP1, ACP-2, ADA-1, ADA-2, AK-1, AK-2, CAT, CK-1, CK-2, DIA, ES-1, ES-2, FUM, GDH-1, GDH-2, GLD-1, GLD-2, G6PDH, GPI-1, GPI-2, HK, IDH1, IDH-2, LDH-1, LDH-2, MDH-1, ME-2, MPI-1, MPI-2, NP, PEP-1, PEP2, PGM-1, PGM-3, PK, SOD-1, SOD-2, and XDH. The loci Mdh-2*, Me-1* and Acy-1* were monomorphic throughout, although Hartl et al. [4] observed biallelic loci with frequencies of $\mathrm{q}=0.018$ for allele $M d h-2^{*} 136, \mathrm{q}=0.093$ for allele $M e-1^{*} 117$, and $\mathrm{q}=0.018$ for $A c y-1^{*} 123$. The sample sizes of $n=27$ in the study by Hartl et al. [4] and $n=48$ in the present analysis are insufficient to demonstrate statistical significance for the apparent loss of the rarer allele in each of the three systems which were polymorphic when sampled before the epidemy, but no longer thereafter. 
Concerning the biallelic locus PGM-2, a significant shift was observed between the allele frequencies of the population samples collected before the $\mathrm{CSF}$ outbreak and thereafter. The frequencies changed from $\mathrm{p}=0.783$ for $P_{g m}^{*}-2 * 100$ before the CSF epidemy $(1988-1989)$ to $\mathrm{p}=0.375$ thereafter (1994-1995), and from $q=0.217$ for $P g m-2 * 113$ before the outbreak to $\mathrm{q}=0.625$ afterwards. The respective sample sizes were 23 wild boars (1988$1989)$ and 48 specimens (1994-1995) respectively. This shift is statistically significant at $\mathrm{p}<0.001$ (chi-square test, $\chi^{2}=20.67$ ). The observed and the expected genotype frequencies of the population sample did not differ significantly $\left(\chi^{2}=0.21 ; \mathrm{p}=0.76\right)$. The genotype frequencies seem to differ among the age classes of wild boars: the number of heterozygotes $(P g m-2 * 110 / 113)$ tended to be elevated among the young boar, however a $\chi^{2}$-test does not prove a significant difference $\left(\chi^{2}=2.57 ; \mathrm{p}=0.11\right)$. The genotypic data did not correlate with statistical significance with the hunting method applied to obtain the respective samples, nor with the sex or the body weight of the individual wild boar.

\section{DISCUSSION}

Three allozyme systems found to be polymorphic by Hartl et al. [4] in the north Vosgian wild boar population prior to the CSF epidemy proved to be monomorphic in the present study, that covered the same sampling sites. Statistical comparisons of the respective allele frequencies were prohibited by inadequate sample numbers in two of these previously polymorphic loci. However, repeated sampling in the same area after the CSF epidemy revealed significantly differentiated allele frequencies at the PGM-2* locus whose zymogrammes were directly cross-referenced in test gels with the variants described by Hartl et al. [4]. We conclude that the shifted allele frequencies in the north Vosgian wild boar within a period of 6-8 years are a biologically valid phenomenon. There are three possible explanations.

\subsection{Genetic drift in situ}

Stochastic genetic drift may have transformed the Pgm- $2^{*}$ frequencies. This explanation appears unlikely when considering the size of the regional wild boar population in the Vosges, estimated at several thousand individuals. Moreover, only three generation steps separate the two sampling seasons if one admits a mean generation length of two years for a wild boar population subject to a. hunting management as it is applied in the Vosges. Seropositive wild boars were homogeneously distributed across the 200000 hectare-sized epidemy zone, there were no unaffected subpopulations remaining which may have expanded when the virus-induced mortality had receded. At last our sampling area was homogeneously sampled.

\subsection{Re-immigration from adjacent populations}

An important immigration event could have transformed the Pgm-2* allele frequencies, particularly if the immigrants had formerly been isolated from the 
autochthonous stock. Young females (30-40 kg body weight) are expected to produce a mean of 2.5 piglets a year, older sows (40-50 kg) 4.25 young, and fully-grown females (>80 kg) 5.5 offspring annually [2]. Therefore a founder effect in an ecological vacuum, caused by the almost-eradication of a local wild boar population due to a disease, could elicit shifted frequencies within a very short time period indeed. This possibility depends on the mortality, the dispersal ecology of the species, and on the availability of source populations.

The pre-CSF wild boar density in the northern Vosges has been estimated at approximately five specimens per 100 hectares. From an annual 35004000 wild boar hunted per year over 200000 hectares before the epidemy, the hunting bag dwindled to 1450 in the hunting season $1992 / 1993$, although the persecution had been intensified to contain the disease. Thus the CSF epidemy might have diminished the wild boar numbers by $50 \%$ at least, or rather more. Reductions were more severe in certain localities, particularly in the source area of the epidemy. Young and juvenile wild boar suffered the highest toll [9]. The population studied was relatively isolated from adjacent populations by a completely fenced motorway in the south, by the Rhine River in the east, and by portions of the Canal de la Marne au Rhin in the southeast which was reinforced by an electrified fence to prevent population exchange. Thus, only the wild boar population of the Pfälzerwald in adjacent parts of Germany could have immigrated during or after the disease.

Long-term population-ecological studies $[3,12,13]$ have changed the traditional view of the wild boar leading a vagabond life. Piglets typically occupy an infant-mother home range of 10 to 20 hectares, the home range size of juveniles is $200-500$ hectares, and subadults ( $8-9$ months to 20 months) range in an area of 1000 to 10000 hectares, with some specimens, chiefly males, ranging further [12]. Upon adulthood, female wild boars settle within a common female group home range of approximately the same extension, and male wild boars range in an area of some 5000 hectares which overlaps the ranges of various sow groups. Dispersal is concentrated in the juvenile age classes, with young males dispersing much further than young females. Hunting may affect dispersal patterns, because social groups disintegrate after the death of female leaders [6]. From 614 wild boars tagged individually in the northern Vosges from 1975-1983, and from 200 tags returned by hunters, the Vosgian wild boars were discerned to travel a few kilometers at most between their place of birth (or site of tagging) and the place where they were hunted [8]. A total of $90 \%$ of all females tagged in the Réserve de Chasse de La Petite Pierre were retrieved by hunters within a $10 \mathrm{~km}$ perimeter around the 2000 hectare area [8]. Longer-distance dispersal was due to juvenile wild boar weighing less than $15 \mathrm{~kg}$, especially young males tagged before one year of age. This dispersal appeared to be stimulated by dissolving familiar bonds at around one year of age [8]. There was no regular or otherwise systematic migration in our study area.

From this database on the population ecology of the wild boar we doubt that population biological factors (i.e. social structure, dispersal, migration) are able to explain the observed transformation of allozyme frequencies in our local population sample over a few years only. 


\subsection{Natural selection}

Hunting records indicate that the swine fever exerted a massive inroad into the north Vosgian wild boar population, but some animals were able to survive the epidemy. These might have provided the bulk of the postCSF founder population. The CSF virus is still present in the local wild boar population, but nevertheless mortality has clearly diminished since the early climax phase of the disease in 1992. Considering the balance of all available evidence, we suggest that the shifted allele frequencies at the PGM-2-locus might be due to differential survival, and better ability of the carriers of the $P g m-2^{*} 113$ allele (or of $P g m-2 * 100 / 113$ heterozygotes) to cope with the CSF virus. The apparent tendency of an increased proportion of heterozygotes, $P g m-2^{*} 100 / 113$, among young wild boars can serve as an indirect hint to differential fitness of carriers of the two PGM-2*-alleles, although the total population sample does not deviate from the Hardy-Weinberg-expectations of genotype frequencies.

\section{CONCLUSION}

The allele frequencies of two allozymes, $P g m-2 * 100$ and $P g m-2 * 113$, differed significantly among population samples collected in the years 1988-1989 and 1994-1996 from the wild boar population inhabiting the northern Vosges (France). Sampling was performed after a major swine fever epidemy. This quite isolated population is known to display the typical non-migratory lifestyle of the wild boar in central European forests [8], so mass immigration of wild boars is considered unlikely. This population is too abundant to explain its microevolution by genetic drift only. The population collapse due to the CSF epidemy constitutes the most plausible cause for this observed shift in allele frequency. The balance of evidence indicates that wild boars surviving the CSF epidemy were not a genetic random sample of the infected population, and that the PGM-2* locus could be a marker for differential mortality, i.e. differential fitness to cope with the viral disease.

The putative population genetic change of a wildlife population occurring in the context of a major virus infection by means of natural selection emphasizes the importance of genetic variability in large mammal populations coping with infectious disease [11].

\section{ACKNOWLEDGEMENTS}

Tissue samples from the Réserve Nationale de Chasse de la Petite Pierre were contributed by J.L. Hamann and C. Martin. The study was supported by a grant from the Fédération des chasseurs du Bas-Rhin. G. Hartl (Institut für Haustierkunde, Kiel University) and F. Suchentrunk (Forschungsinstitut für Wildtierkunde und Ökologie, Veterinary University, Vienna) kindly provided genotyped reference tissue samples. 


\section{REFERENCES}

[1] Barthélémy V., Contribution à l'étude de l'épizootie de peste porcine classique chez les sangliers sauvages survenue dans les Vosges du nord en 1992, Thèse de Doctorat Vétérinaire, Alfort, 1994.

[2] Bouldoire J.L., Vassant J., Le sanglier, Hatier, Paris, 1989.

[3] Gérard J.F., Teillaud P., Spitz F., Mauget R., Campan R., Le sanglier, in: Campan R., Bon R., Barre V. (Eds.), Les Ongulés sauvages de France. Revue d'Écologie, Numéro Spécial 6, 1991, pp. 11-66.

[4] Hartl G.B., Markov G, Rubin A., Findo S., Lang G., Willıng R., Allozyme diversity within and among populations of three ugulate species (Cervus elaphus, Capreolus capreolus, Sus scrofa) of Central Europe, Z. Säugetierkund., 58 (1993) 352-361.

[5] Heck L., Raschke G, Die Wildsauen. Naturgeschichte, Okologie, Hege und Jagd, Paul Parey, Hamburg, 1980.

[6] Janeau G., Gallo Orsi U., Wild boar session and workshop: Comments and conclusion, in: Spitz F., Janeau G., Gonzales G., Aulagnier S. (Eds.), Ongulés / Ungulates 91, Toulouse, 2-6 septembre 1991, S.F.E.P M.-I.R.G M, ParisToulouse, 1992, pp 383-384.

[7] Kern B., Depner K.R., Letz W , Rott M., Thalheim S., Nitschke B., Plagemann R., Liess B., Incidence of classical swine fever (CSF) in wild boar in a densely populated area indicating CSF virus persistence as a mechanism for virus perpetuation, Zent. Veterinarmedicin [B], 46 (1999) 63-67.

[8] Klein F., Marquage de sangliers à la Petite Pierre: Premiers résultats, Office national de la chasse - Bulletin Mensuel, 45 (1981) 21-26.

[9] Lang S., Le sanglier. Étude de la diversité génétique de populations naturelles après l'épidémie de peste porcine en Alsace, Thèse de Doctorat en Pharmacie, Strasbourg, 1998

[10] Radigue H., Contribution à l'étude de la lutte contre la peste porcine classique. Bilan de la récente épizootie (1988-1989) survenue en région Rhône-Alpes, Thèse de Doctorat Véterinaire, Nancy, 1991.

[11] Schreiber A., Tichy H., MHC polymorphisms and the conservation of endangered species, in: Moore H.D.M., Holt W.V., Mace G M. (Eds.), Biotechnology and the conservation of genetic diversity, Oxford Unuversity Press, Oxford, 1992, pp. 103-121.

[12] Spitz F., General model of the spatial and social organization of the wild boars (Sus scrofa L.), in: Spitz F., Janeau G., Gonzales G., Aulagnier S. (Eds.), Ongulés / Ungulates 91, Toulouse, 2-6 septembre 1991, S.F.E P.M.-I.R.G.M., Paris-Toulouse, 1992, pp. 385-389.

[13] Stubbe C., Mehlitz S., Peukert R., Goretzki J., Stubbe W., Meynhardt H., Lebensraumnutzung und populationsumsatz des Schwarzwildes in der DDR Ergebnisse der Wildmarkierung, Beiträge zur Jagd-und Wildforschung, 16 (1989) $212-231$.

[14] van Oirschott J.T., Hog cholera, in: Disease of swine, IOWA United Press, Ames, USA, 1986, pp. 289-300. 